\title{
The Advance of Herring Research
}

$\mathrm{O}^{\mathrm{N}}$ N April 21, 1881, Prof. T. H. Huxley delivered a striking lecture at Norwich on the herring, during the National Fishery Exhibition held there. Reference to the text of that lecture (published in full in the issue of NATURE of April 28, 1881) shows that Huxley made the following statement: ". . And all kinds of real knowledge and insight into the facts of nature do so bear upon one another and turn out in strange ways practically helpful, that I propose to pour out my scientific budget, in the hope that something more may come of it than the gratification of intelligent curiosity". Fifty-four years later, in the same city of Norwich, during the recent meeting of the British Association, the members of Section D (Zoology) listened to a symposium on the herring problem which demonstrated beyond any doubt the truth of Huxley's assertion, and realised his hope. Indeed, the symposium can best be described as an account of current investigations for the express purpose of rendering direct assistance to the commercial herring industry, not only by predicting the quantity and quality of the fish likely to be available during an impending season, but also by stating where and when nets should be set in order to secure the best possible catches. That is to say, the 'problem' with which the symposium really dealt was the entirely practical one of how to aid industry by scientific research.

The four papers of the symposium were read by Mr. E. Ford, Dr. W. C. Hodgson, Prof. A. C. Hardy and Mr. R. S. Wimpenny, in the order named. The first paper confirmed and extended Huxley's view that practised eyes distinguish local breeds of herring, dealing in particular with the study of vertebral variation as evidence in this connexion. It was shown that although the simple count of the total number of vertebræ in a herring falls far short of the ideal specification of so important an organ of the body as the backbone, its use as a statistical character in population studies has proved of very material assistance in acquiring knowledge of the life and movements of the different local forms of herring within their own limited territories of the sea. Using the average number of vertebræ for a sample of herrings as a statistical estimate of the average for the population from which the sample was drawn, real population differences have been demonstrated by comparing sample with sample : and by considering the results in conjunction with corresponding differences in other characters, the 'ground-plan', as it were, of the complex of local forms by which the species Clupea harengus is represented has gradually revealed itself. The reliability of this work remains unaffected by the fact that scientific opinion is at present divided as to the precise nature of a local form of herring, and the parts played by heredity and environment in preserving its continuity from generation to generation.

Having learned the essential facts in the lifehistory of the particular local form with which he is concerned, an investigator may then inquire into the factors which determine the success or failure of the commercial fisheries based on that local form. Important researches of this kind in connexion with the great East Anglian drift-net fishery in the Southern North Sea formed the subject of the second paper in the symposium. The sharp and irregular fluctuation in the annual yield of the fishery is partly accounted for by the natural waxing and waning in numerical strength of the fishable stock. This, in its turn, is a sequel to the unequal production of young from year to year. Reliable evidence, direct or indirect, as to the brood production of to-day is therefore a portent for good or ill in the fishery of to-morrow. Hence, the announcement that there is indication of a positive correlation between brood production and the January temperatures of the sea, in the vicinity of the Varne lightship, is one of much interest and promise.

Inequality of brood production, however, does not entirely account for good and bad fishing yield. Whether the fishable stock be rich or poor, the best possible catches will only be made when fishing is conducted at the right time in the right place. It is important to know that the yield is best at the time of full moon, and that the most favourable conditions for a productive season is when the October full moon occurs during the second week. The conditions of wind blowing over the fishing grounds must also be taken into account, for it is held that herrings tend to swim into the wind ; and it is easy to understand that persistent winds from an unusual quarter may cause the shoals to move away from places which they normally visit and where fishermen expect to find them.

It is not only in connexion with the great East Anglian exploitation of shoals making their way to the spawning grounds that scientific investigation is proving its worth. We know that, in the intervening months between annual spawning migrations, the shoals are ranging the sea in 
search of food. Information as to the places in which such shoals are likely or unlikely to be found is thus of real value to fishermen wishing to intercept them. Work in this direction was described in the third and fourth papers of the Norwich symposium. Ingenious instruments and methods have been used in a comprehensive and continuous survey of the floating animal and plant plankton of the North Sea with relation to the movements of herring. Positive correlations between the number of herring caught and their food Calanus, and negative correlations with phytoplankton, have already been demonstrated. The practical outcome of this is that fishermen can be assured of a greater return for a season's labour if they will regularly use a plankton indicator in deciding where to set their nets. It has also been shown that the phytoplankton at times forms dense patches which interfere with the movements and shoaling of herring, with serious consequences to the dependent fisheries. The study of the origin, disposition and fate of these patches, therefore, is in itself of major interest to the industry. We must also know whether the observed tendency for the autumn herring shoals. of both 1933 and 1934 to mass against the edge of a diatom patch is a regular phenomenon.

A word or two must suffice to deal with a line of investigation about which the symposium was silent. Nothing was said regarding the urgent necessity of a greatly improved market for herrings, to prevent the complete collapse of the British industry. For of what use to the fishermen is scientific aid in his fishing if he cannot sell the catches he is already making without such aid?

E. FORD.

\section{Erosion Surfaces}

GINCE Ramsay recognised in 1878 that the $S$ even skyline of South Wales represented a plain of marine denudation, uplifted and dissected, upland surfaces of low relief have been recognised in all parts of the world, and their probable relation to the great unconformities of the stratified rock succession has been discussed. Some, following W. M. Davis, have preferred to regard them as sub-aerial peneplains rather than marine features, but few certain criteria exist for distinguishing subaerial from submarine surfaces, after uplift and dissection, and each case must be judged on its merits. Recent years have witnessed a concentration of interest upon such features, commonly known as 'platforms'. In America, the work of the late Joseph Barrell, and of D. W. Johnson, has emphasised the importance of this line of study. A committee of the International Geographical Congress, on which Prof. A. G. Ogilvie is the British representative, is at present seeking to organise the work of mapping erosion surfaces in Europe, using an agreed, though tentative, scheme of symbols. Interest has also been fostered by the publication of Prof. Baulig's recent monograph $^{\mathbf{1}}$ in which high-level platforms are discussed in the context of the daring theory of major eustatic changes of sea-level.

With the field thus fertilised, Sections C (Geology) and E (Geography) devoted a session to a joint symposium and discussion on "Denudation Chronology" at the Norwich meeting of the British Association on September 9. The regions discussed included south-east England, Devon and
Somerset, South Wales, southern Ireland, the East Midlands, Yorkshire and the Channel Islands. Any attempt fully to correlate work from so wide an area would be premature, but a most welcome concurrence of opinion was manifest both as to the methods of research and the general results obtained. The histories of denudation in the several areas proved indeed so generally comparable as to point a most hopeful future for such investigation and to foreshadow theoretical results of high importance.

An initial problem to be solved in most areas is the differentiation of older surfaces-stripped planes of unconformity, from those formed during the middle and later portions of Tertiary time. There is a general tendency among the students of the older rocks tacitly to underestimate the erosional work of Tertiary time, and to regard the dominant hill-top surfaces of relict Palæozoic uplands as the basal planes of Triassic, Jurassic or Cretaceous rocks, which, buried far beneath the adjoining plains, rise to join the hill-top surface of the 'Massifs', thus signifying a former wide extension of the sediments above them. So cavalier a dismissal of some sixty million years of geological work is theoretically unacceptable, and as a hypothesis it fails to fit the facts. Wherever they are examined in Britain, the 'fossil peneplains' of pre-Permian to pre-Cretaceous date are relatively steeply inclined away from the Palæozoic uplands. Even if their slope flattened as traced away from the heavily loaded areas of the plains, they must nevertheless have passed far above the 